\title{
The Hegemony of Western Pop Music in Indonesia 2010-2020 Period
}

\author{
http://dx.doi.org/10.25008/jkiski.v6i2.583 \\ Andre Ikhsano $^{1 *}$, Jeremy Asido Sianipar ${ }^{2}$ \\ ${ }^{1,2}$ Communication Study in Postgraduate Programme, Institut Komunikasi dan Bisnis LSPR \\ Sudirman Park, Jl. KH. Mas Mansyur Kav. No. 35 Jakarta 10220 - Indonesia \\ "Corresponding author: andre.i@1spr.edu
}

Submitted: June 22, 2021, Revised: September 23, 2021, Accepted: October 15, 2021

Accredited by Kemristekdikti No. 28/E/KPT/2019

\begin{abstract}
One of the strong and real cultural dominations in Indonesia is the dominance of Western pop music. In this case, there is a voluntary acceptance by the Indonesian people of Western pop music which leads to the concept of Gramsci's hegemony. The continuity of the hegemony of western pop music in the country has been going on for a very long time, for that of course there is a need for deeper advocacy of the hegemony of western pop music so that the Indonesian people are aware of the 'colonialism' of western pop music in the country. This critical paradigm research is supported by a qualitative approach based on the theory of hegemony and supported by the concept of cultural imperialism. The findings of this study are the hegemony of western pop music that is widespread and civil society, namely, the Indonesian people tend to accept it with joy so that it seems that it even perpetuates the hegemony itself. Meanwhile, in the aspect of political society (government), various efforts have been made in advancing the national music industry; but are still considered less than optimal.
\end{abstract}

Keywords: Civil Society, gramsci, hegemony, western pop music, political society

\section{Introduction}

The presence of globalization in every dimension of people's lives has an impact on the spread of pop culture. Storey (2006) defines popular culture as a culture that is widely liked and works done to please people. According to Ardia (2014), pop Culture is a concept that produces a product called popular culture that is liked by many people. The existence of popular culture itself is a form of resistance to the upholding of high cultural values or what is often referred to as elite culture in the process of glorifying cultural values, namely the culture produced by intellectuals.

Pop culture is a cultural work that cannot be included in the criteria of high culture. Pop culture referred to in this context is as stated by neo-Gramscian circles. The concept of pop culture cannot be separated from the term hegemony as conceptualized by Antonio Gramsci who said that hegemony is a view of life and a dominant way of thinking; in which a concept of reality is disseminated in society both institutionally and individually. In this case, ideology dictates all tastes, moral customs, religious and political principles, and all social relations (Hatmoko, 2014). It can be said that hegemony is an act of domination through the flow of culture carried out by the dominant to the inferior. Various cultures that are imposed globally are such as fashion, food, lifestyle, and even the art of music (Ardia, 2014).

America or what has often identified with the West as well as the dominant class society; is the perpetrator of the spread of culture because America has a very large economic intensity. Surely, even Indonesia cannot escape 
the influence of American power. Apart from economic and political matters, America's influence in culture is also very strong. One of the flare-up American cultures in Indonesia is music. America, which upholds the values of liberalism, of course also affects the freedom of its people to express themselves, including in the field of music. This is evidenced by so many bands, singers, and music made into an industry. And with its strength, their music is not only listened to locally but also internationally including Indonesia (Hegemoni Musik Indonesia, 2018).

In Indonesia itself, there are many music services and digital streaming applications that provide several charts. Like Spotify, Apple Music, iTunes, Joox, SoundCloud, and other similar apps.

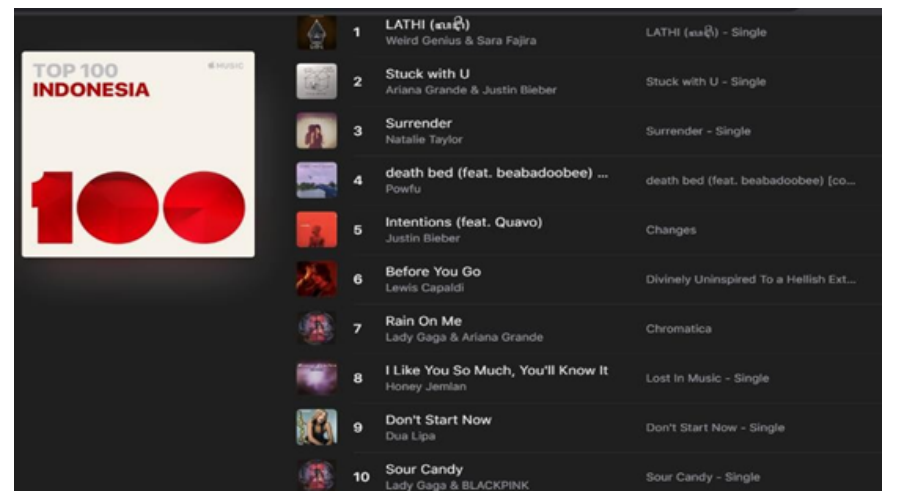

Figure 1. Indonesian Music Charts in the Apple Music Application (Apple Music, 2019)

If seen in Figure 1 above, it is very clear that western pop music dominates the Indonesian music charts. Original songs from Indonesian musicians are very rarely found on various Indonesian national charts. Western Pop Music is not only about who the creator or composer of the music is, but also what must be communicated to a wide audience so that a song or music becomes popular. As stated by Rojek (2011) that:

"Musical communication depends upon several historical and social particulars that are independent of the artist, Pop presupposes linguistic, historical, and cultural conventions. to be sure, creative artists seek to express this or that emotion, belief or value in a form that audiences will find compelling".

When music does not only talk about artistic aspects but various kinds of economic, political, and other interests are also dragged into the big wave of pop music hegemony in Indonesia; become a very interesting thing to explore. Therefore, the main objective of this research is to explore the hegemony of western pop music in Indonesia for the period 20102020.

\section{Theoretical framework}

The concept of hegemony itself was born and developed in the flow of Marxist thought.
Hegemony as a theory was born from the thinking of the Marxists in Russia in facing the Russian monarchy; therefore, almost all debates about hegemony flow in the currents of Marxist thought. But lately, the concept of hegemony is positioned to be more neutral in viewing various forms of power relations, both in terms of politics, literature, economy, society, and culture (Hutagalung,2004).

Hegemony is a chain of victories that is obtained through a consensus mechanism rather than through oppression of other social classes. Various ways are used, for example through existing institutions in society that directly or indirectly determine the cognitive structure of society. In essence, hegemony is an effort to lead people to assess and view social problems within a predetermined framework without any coercion by force (Nezar \& Arief, 1999). In general, hegemony is a process of domination of power by one social class over other social classes, through intellectual and moral leadership which is supported by oppression or domination. Hegemony can also be defined as domination by one group over another, with or without the threat of violence, so that the ideas emphasized by the dominant group against the dominated group are accepted as natural (Sugiono, 2006).

The concept of the theory of hegemony initiated by Gramsci is a view of life and a dominant way of thinking, in which a concept of reality is disseminated in society both 
institutionally and individually; ideology dictates all tastes, moral customs, religious and political principles, and all social relations, especially in the intellectual and moral sense (Nezar \& Arief, 1999). In Gramsci's eyes, the ruled obey the ruler; then those who are controlled must not only feel they have and internalize the values and norms of the rulers, more than that they must also approve their subordination. This is what Gramsci meant by "hegemony" or consensual control with "moral and intellectual leadership" (Gramsci, 1976). Gramsci contrasts hegemony, as a form of the supremacy of one group or several groups over another, with another form of supremacy which he calls "domination", namely power supported by physical force (Gramsci, 1976). Gramsci's concept of hegemony can also be elaborated through his explanation of the basis of class supremacy:

"the supremacy of a group manifests itself in two ways, as 'dominance' and as 'intellectual and moral leadership'. And on the one hand, a social group dominates the opposition groups to "crush" or subdue them, perhaps even using armed force; on the other hand, social groups lead their groups of relatives and allies. A social group can and should even have exercised "leadership" before winning governmental power (such leadership is one of the main conditions for winning such power). The social group then becomes dominant when he exercises power, but even if he has full power in his hands, he still has to continue to "lead" too" (Gramsci, 1976).

The quote clearly shows a totality that is supported by the unity of two concepts, namely leadership (direction) and domination (dominance). The relationship between these two concepts implies three things. First, domination is exercised over all enemies, and leadership is exercised over all allies. Second, leadership is a precondition for conquering the state apparatus, or in a narrow sense state power can be achieved, these two aspects of class supremacy continue, either direction or domination (Nezar \& Arief, 1999).

Gramsci's theory of hegemony requires the use of state coercive power only as a last resort when "spontaneous consciousness fails" (Gramsci, 1976). This further shows that only the powerful group relies on its weaknesses. A hegemonic relationship established by the ruling group succeeds in getting the subordinate groups above and culturally subordinate to them. In other words. subordinate groups accept the ideas and political interests of the ruling group as their own. Thus, the legitimacy of the ruling group is not challenged because its ideology, culture, values, norms, and politics have been internalized as its own by subordinate groups. Once this consensus is obtained, ideology, culture, values, norms, and politics are increasingly seen as "natural and legitimate and this means that the use of coercion by the state becomes unimportant (Suryawan, 2010). Hegemony can be interpreted as a dominating action through various aspects, especially in research carried out through culture by the dominant (western) people to the inferior (Indonesian society) so that various kinds of cultures are imposed globally such as fashion, food, lifestyle, music, films and so on. (Ikhsano \& Stellarosa, 2020).

Gramsci also revealed that the consensual that is owned by the community towards a moral and intellectual leadership is built through two elements, namely political society and civil society which incidentally is the development of Gramsci's thinking on the Marxist theory of Base and Superstructure. Gramsci divides Marx's Superstructure into two elements, i.e. elements of political society (political circles, such as the state, police, military, etc.) society itself) and civil society (community organizations, such as educational institutions, religion, and also the media) which are in power with the approval of the community (through culture, ideology, views, beliefs, and even the arts that can influence people's approval of civil society itself). Therefore, Gramsci concludes as "not as the sphere of freedom but of hegemony" (Buttigieg, 1996).

Political Society and Civil Society cannot be separated and are mutually in quality with one another, the existence of power obtained through domination only lasts for a short time and along with globalization and public anxiety about the dominance possessed by political society, sooner or later will cause a revolution to take place against absolute domination. Therefore, the power obtained through physical domination will turn into domination over the consent of the community itself (hegemony) because with the legitimacy of the power of an entity over society, the community will justify and approve of the domination and view it as a truth that should exist and be in the community. believe. 
In other words, the hegemony of one group over other groups in the Gramscian sense demands something that is forced. Hegemony is also understood in a strategic context where the views and power of role models of social groups (whether in the form of class, ethnicity, state, institution) are maintained. (Ikhsano, 2020) This hegemony must be achieved through political, cultural, and intellectual efforts to utilize a common worldview for the whole society. This means that the ruling group must "universalize" its views and interests and must ensure that they not only can but must also become the views and interests of subordinate groups (Gramsci, 1976).

\section{Material and Methodology}

Referring to the critical paradigm; this research tries to dismantle the ideological veils and hegemonic practices of western pop music in Indonesia. Hegemony which is included in the category of critical theory is felt to be relevant to the critical paradigm used. This emancipatory critical paradigm tries to provide enlightenment and advocacy to the public. A qualitative approach is used in this study for more in-depth disclosure. Data was collected by interviewing various sources; (1). AJG - Deputy for Intellectual Property Rights and Regulatory
Facilitation (BEKRAF); (2). DX-radio announcer on Phoenix FM Radio Bali; (3). MA Musician, public figure, artist, and 4). IVRConnoisseur and avid fan of western pop music.

\section{Result and Discussion}

In Indonesia, pop music has developed since the 1960s and is very popular with the public, especially teenagers. Pop music groups are often referred to as bands that use electronic or modern equipment (Fase Berita, 2019). While Western Pop Music can be interpreted as music that has a pop genre but is produced by musicians outside Indonesia, in this context, Western is Hollywood or the United States. Pop music and market logic are inseparable dualisms. The cooperation of the two has major implications for the formation of ideology for the people who support it. Pop music and market logic are dualisms that cannot be separated. The cooperation of the two has major implications for the formation of ideology for the supporting community (Adorno, 1953).

The music industry is one industry that is also concentrated. From a macro perspective, the recording industry has almost the same thing as other mass media, namely experiencing a concentration of ownership.

Table 1. World Music Industry Conglomeration Order

\begin{tabular}{clll}
\hline Order & $\begin{array}{l}\text { Industry } \\
\text { Conglomerate }\end{array}$ & Label & Artist \\
\hline 1 & $\begin{array}{l}\text { Universal Music } \\
\text { Group }\end{array}$ & $\begin{array}{l}\text { Geffen, Island } \\
\text { Def Jam, Motown }\end{array}$ & $\begin{array}{l}\text { U2, Selena Gomez, } \\
\text { Lady Gaga, Drake }\end{array}$ \\
\hline 2 & Warner Music & $\begin{array}{l}\text { Atlantic, Warner } \\
\text { Bross, Maverick }\end{array}$ & $\begin{array}{l}\text { Madonna, Ed Sheeran, } \\
\text { Dua Lipa }\end{array}$ \\
\hline 3 & Sony BMG & Arista, Epic, Jive & $\begin{array}{l}\text { Beyonce, Britney } \\
\text { Spears, Jessica Simpson }\end{array}$ \\
& & Cirgin, Capitol, & $\begin{array}{l}\text { Coldplay, Keith Urban, } \\
\text { KT Tunstall }\end{array}$ \\
\hline
\end{tabular}

Source: Pramudyanto, 2013

The problem that occurs is when the western (American) pop music industry dominates the country's music; including radio and digital platforms services. There is the term "The Big Four" as the nickname of the 4 big companies that dominate the business of more than $85 \%$ of the American market, and $75 \%$ of the global market includes Indonesia (Dominick, 2009).

The four companies have affiliates in Indonesia and control the distribution of music for international artists (American artists), until now, no policy regulates the scheduling of the release of American pop songs in a controlled manner so that western pop music distribution is still free to carry out without any release restrictions juxtaposed with local Indonesian musicians.

\section{The Hegemony of Western Pop Music in Indonesia}

The entry of Western Pop Music in Indonesia involves the Indonesian people themselves, because in this global era every musician is free and has the right to release or promote his work through various available media, and the role of the community or audience (listener) is one of the determinants of a work entering a country. It can make Indonesia pop music dominant in Indonesia 
itself, or even make western pop music dominant in Indonesia. AJG as Expert Staff to the Minister for Bureaucratic and Regulatory Reform at the Indonesian Ministry of Tourism and Creative Economy said:

"Music also depends on people's tastes, when people appreciate nowadays, for example, people appreciate western songs, okay!, maybe later many western songs will appear on the radio, but maybe someday people will appreciate mandarin songs, for example, because at that time, there is a film series Tao Ming Tse for example; maybe people are eager to hear mandarin songs, then there is the Korean Wave, now people are enthusiastic to hear K-pop songs, so there's a lot of people in my opinion like that."

The presence of western pop music cannot be avoided, because every artist and musician has the right to launch his work on various media platforms, so it is time for local musicians (Indonesian musicians) to present works that adapt to the target audience or market tastes, so that they can compete with western musicians, especially in Indonesia itself, as in his opinion:

"Everyone has a different taste in music, in the sense that maybe there are people who like Indonesian music, some like western music, or like foreign music. Because it's a matter of taste. So, I think that's why we can't avoid it if many people prefer foreign music or western music. But again, this should actually be a whip or trigger for local musicians to maybe improve their quality, so that the music they produce can suit the tastes of the market, and now I think many local musicians can provide or produce music that finally attracts local interest."

In the era of globalization, it is no longer relevant to interpret culture from the point of view of ontology. Contemporary culture is no longer a matter of preserving ancient objects, preserving ancestral traditions or values. The meaning of culture today is the personality or identity of a nation. Still ringing that when the cold war began in 1945, the United States was keen to carry out cultural diplomacy through the media of music. Cultural diplomacy is intended to build a positive image of Uncle Sam's country. Understandably, during the first and second world wars, the United States was labeled as a war-loving country. The US wants to be known as a peace-loving country. The US is not kidding about this, cultural diplomacy is getting louder. In 1954, the 34th US President, Dwight Eisenhower, sent music experts to various countries to spread music under the guise of an emergency fund. Eisenhower also formed the American National Theater and Academy (ANTA) in which there is a special division in the field of music, namely the Music Advisory Panel. The US cultural diplomacy program has proven to be successful. While diving into drinking water, the US also uses ANTA to spread its ideological understanding. It's hard to argue, the world's music industry is now oriented to the west, especially the United States. Musicians can be considered top-notch if they can penetrate the Hollywood music market (Amroshy, 2014).

The rapid development of American Pop music in Indonesia resulted in a decrease in the interest or taste of the Indonesian public towards local or traditional music that led to local culture being pressured by pop culture, especially those from America, which resulted in the perception that American pop music was more modern. This concept refers to the term cultural war in the form of political and economic forces that attack subtly the basic principles and cultural elements of other nations. The culture war was carried out quietly, invisible, so it did not generate noise and attract attention. In the end, the country that wins the culture war is the country that will rule the world. The United States has proven that through music (Khamenei, 2005).

\section{The Entry Period of Western Music in Indonesia}

In the ' 60 s, President Soekarno had also tried to restrain the invasion of western music. Soekarno, who has high artistic blood, created the Lenso music genre, inspired by Maluku culture. Soekarno wanted the lenso rhythm to be a style of Indonesian music that would fight the dominance of western music which was popular at that time. Soekarno invited famous musicians such as Gesang, Titiek Puspa, Bing Slamet, Rita Zahara, Nien Lesmana, Jack Lesmana, and others, to work on an album with the lenso music genre. Soekarno also co-composed a song entitled Bersuka Ria. On April 14, 1965, Lenso's album was released entitled Rejoicing with Lenso Rhythms. Moving into the decade of the 70 s to the 80 s, musicians such as Koes Plus and Panbers and other musicians, began to be born by carrying the rock $\mathrm{n}$ roll genre that was hit at that time. Despite choosing the genre of 
rock music, musicians like Koes Plus do not hesitate to give an ethnic touch to their works. The Indonesianness is thicker. Koes Plus has also made albums such as Tul Jaenak and Ojo Nelongso by carrying the Javanese Pop flow. The band, fronted by Yon Koeswoyo, is also not shy about making songs with Melayu rhythms such as the song Mengapa, keroncong songs such as Cinta Mulia, and Singer Tua. Panbers too, in Album Vol. I, they inserted a Batak song entitled Masihol Ahu. Unexpectedly, the touch of the Batak rhythm received a positive response on a national scale. Since then, Panbers has been a pioneer of Batak songs and a role model for Batak musicians in the recorded music industry (Indana, 2017).

Looking at the current millennial generation, it can be predicted that the domestic music market has been infected with western music. The proof can be seen in today's society, which has become westernized. Young people imitate the western lifestyle, starting from how to dress, socialize, speak, and so on. You could say, Indonesians have begun to be westernized. It didn't stop there; the Korean wave or South Korean music wave began to penetrate the Indonesian music market in early 2000. Popular Korean music known as K-Pop or Korean Pop exploded in 2011. Since then, the K-Pop fever has spread to all corners of the country. K-Pop always presents boyband and girlband formats which generally have a large number of personnel, wrapped in modern music rhythms. K-Pop artists are sure to be good at dancing and have beautiful and fresh faces. K-Pop always amazes fans through a cohesive dance. As a new player, South Korea has succeeded in spreading its cultural influence through music.

In the era of 2010 until now, the dominance of Western pop music has certainly managed to regain control of the music market in Indonesia. This is supported by data obtained by researchers through digital song sales data and streaming charts on various music platforms as follows:

Table 2. List of Digital Song Sales in Indonesia

\begin{tabular}{cllc}
\hline Rank & Artist & Title & Sales \\
\hline 1 & Weird Genius & LATHI (feat. Sara Fajira) & 8 \\
\hline 2 & Ariana Grande \& Justin Bieber & Stuck With U & 6 \\
\hline 3 & Raiden \& Chanyeol & Yours (feat. Lee Hi \& Changmo & 6 \\
\hline 4 & Honey Jemlan & I Like You So Much, You'll Know ] & 4 \\
\hline 5 & Natalie Taylor & Surrender & 3 \\
\hline 6 & Lauv & Love Like That & 3 \\
\hline 7 & Kim Yuna & Lonely Sailing & 3 \\
\hline 8 & Melanie Martinez & Play Date & 2 \\
\hline 9 & SHAUN & Way Back Home (feat. Conor & 2 \\
& & Maynard) [Sam Feldt Edit] & \\
\hline 10 & IU & Eight (feat. SUGA) & 2 \\
\hline
\end{tabular}

Source: Digital Sales Data, 2020

Based on the data above, it can be seen that the dominance of western pop music in nine chart positions, with a total sales figure of 29 .
Indonesian pop music itself only gets one place in the top 10 song sales positions in Indonesia.

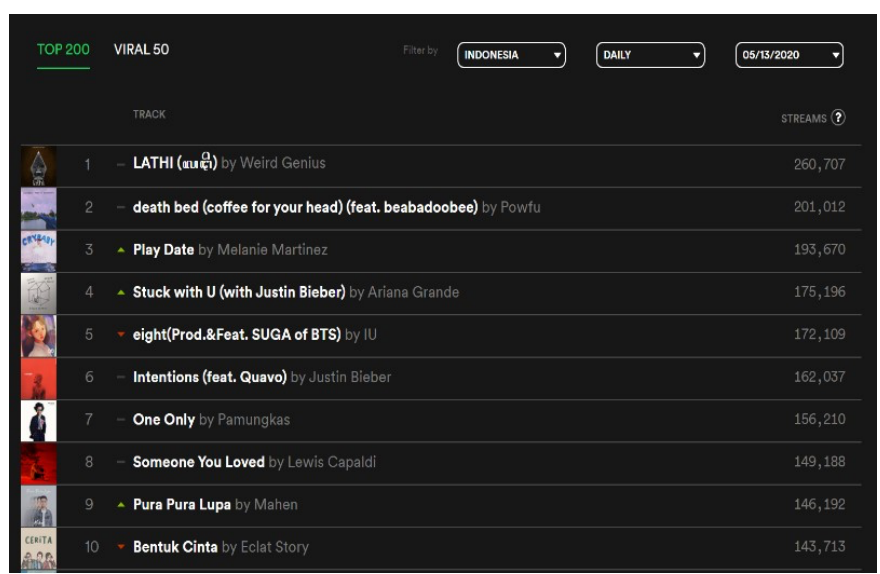

Figure 2. Spotify's top charts in Indonesia (Spotify, 2020) 
In the Spotify application, it is also clear that only four Indonesian songs occupy the top 10 songs, this can change every day. However, in the monitoring of researchers from November 2019 to May 2020, the chart data is still dominated by western pop music.

\section{Civil Society and Media Hegemony of Western Pop Music in Indonesia}

In the object of the Indonesian music industry, Civil Society and Public Media are the musicians, fans, and the role of the radio.

(1). Musicians are very important figures in the music industry, because they are the ones who create a work, present their work to a world audience, and perpetuate energy, feelings, creativity, and ideas or goals into work or song. Mutiara Azka, a musician, recording artist, and activist, is a source person interviewed by researchers. The vastness of music genres currently ignores her choice of Pop Music and has musicians from abroad and domestically as a musical priority for a musician like MA. She said;

"Lately, Indonesian music has started to catch up, but back then West, the concepts are intended from the beginning, even KPop is all conceptualized, themes, names, colors, everything is there. So it's all integrated. Suppose when they wrote a song, for example, EXO, let's take an example. That Obsession album, we think this obsession is about obsessive people or what turns out there's another theory. Behind that, they are fighting their own alter ego, so they are back and forth. There are a lot of concepts, it's like connecting and super, what's the name, continuity, all in all, the creativity is great in the west."

The expression conveyed by MA shows that the comparison of music between Indonesia and abroad has inequality in terms of creativity, the mature concept of a foreign musician has not been found enough in local (Indonesian) musicians. The interesting thing about her works is the songs released in English. She's main goal in creating English works was not initially to make a profit in the Indonesian music market, through wanting her works to be heard by listeners from all over the world through a universal language, which is English.

"I wanted to write in Indonesian, but again I had time to study abroad and I was able to participate in an event, not an event, yes, I networked there, especially when I was in Australia, like America, Australia is a melting pop and that's how we communicate. With Indians, Japanese, Koreans, British, it's in English, because it's a universal language, so I want my song to reach the global community, like my friends who are abroad can also enjoy my songs. This is a personal reason anyway."

Musicians are not far from other musicians who inspire them in the projects they work on. Like MA herself; she admits that she is influenced by foreign (western) pop musicians: "Because I like musicals and pop musical songwriters, Sara Bareilles is also the likeness of Taylor Swift." She also admitted that for now there are no local (Indonesia) musicians who influence him in terms of music.

(2) Radio can be a barometer in measuring the success of a song seen from several charts in each radio station. In this case, the researcher had the opportunity to interview a radio announcer from Phoenix Fm, DX. He is not only a regular radio broadcaster but also a singer and presenter, so the researcher believes that he has a view on the hegemony of pop music in Indonesia. DX responded to the hegemony of western pop music in Indonesia as a widespread epidemic.

"The truth is, in the broadcasting world, I never want to use those words, but actually when I broadcast, I really use languages that everyone can understand, especially my radio segment is for young people, so if I use language that is too standard, it means people won't understand, right, it's just my reasoning, I seem to have an understanding, what kind of hegemony is it, an epidemic. So, something widespread."

DX does not hesitate to reveal that western pop music is currently the prima donna on his radio station chart, and believes that the role of radio must have something to do with the success of musicians. The percentage between Indonesian music and western music is considered quite relevant, so it can be investigated how far western pop music dominates in the radio sector. DX also responded as follows:

"In Phoenix itself, it depends on the program, so there are indeed programs that free us to play any song, there are programs that, indeed, from the title of the program, 
have shown that we can only play certain songs. For example, there is a program called "Ini Indonesia" where for 3 hours of the prime time it is only allowed to play Indonesian songs, domestically produced. I don't know if the song is in English, but if it is produced domestically, it can still be played. But for other programs, most of these programs are general, so you can play any song. But certain taping programs only play, for example, Asian songs, Asian Hits, K-Pop, and so on, depending on the number of requests and we are currently paying attention to what kind of audience requests."

It is undeniable that the number of requests will determine which song dominates which country. It was also explained that the situation affected the listener's request; for example, if there is a film that is on the rise, then the song from the film is requested by many fans, or for example if a big musician is releasing a new single, usually, a lot of requests will be made by fans. This is as conveyed by DX: "but this is back to what, huh, what's hot in the audience, for example, when there are films that are booming, there must be a lot of requests for the songs in the film".

So, a moment will also determine the success of music in the radio realm, but he also said that from the whole or in general, it can be said that Western Music is still the number one place for listeners to request songs on the radio station where Dimas works: general, the red line is drawn, there are too many songs," he said.

All radios must have a standard percentage of song playback between Indonesia and the West, but that is not an absolute thing, it is adjusted to the radio program, and to the purpose of the program itself; such as a program that only plays Indonesian songs, the broadcaster will play $100 \%$ of the songs produced by Indonesian musicians. DX stated this as follows:

"I have it in my program. So, the percentage can be said to be 70:30, 70\% Western songs, $30 \%$ Indonesian songs. Because my program is next to the Indonesian program I mentioned earlier, so if for example, I play too many Indo songs, I'm afraid that people or the audience in the program after me will decrease, so the percentage for me is 70:30. So I have to be more dominant playing western songs."
If it is drawn from the operational hours of the Phoenix FM radio, which is from 5 AM to 12 PM, throughout the broadcast, Dimas stated that it is the Western Song that still dominates on their radio station. It can be seen from the 3 main charts owned by their radio station: "it is proven that we have 3 main charts, only 2 charts are dominant for western songs, so we have 3 , namely top40, request box, and Indo 19". It is clear that the songs that are often played are western.

(3) Music Fans; Fans are the most visible part of pop culture practice. Fans are ideal consumers because their consumption habits can be said to be so high that they are easy to read and predict by the culture industry and are often stable (Hills, 2002). Fans have always been characterized as potential bigots. This means that fan groups are seen as excessive and close to insanity. IVR is a fanatical fan of Western Music; she is a student at a private university in Jakarta. she explained that he was very interested in western pop music because western pop music, according to him, was of higher quality than Indonesian music: "I'll be honest, I prefer western pop, because it's like, the songs are better, the lyrics are really good, that's for sure because I idolize foreign artists too, so it feels like I love the songs too." She even admitted that almost $100 \%$ of the songs on his cellphone were western songs; works by Shawn Mendes and Justin Bieber dominate song playlists on IVR mobile phones. She continued that the reason why she didn't like songs by the nation's children was that the choices were limited and only a few met the standards of this female student: "To be honest, only a few Indonesian songs are pleasant to hear, like you can count your fingers, while the western songs are easy to listen to. There are many choices, and the songs are nice to listen to."

The influence of consumerism on downloading western songs is indeed one of the reasons why Western songs often dominate in our own country. IVR explained that the efforts that must be made by local musicians to be more loved by the Indonesian people are to improve the quality and use the Universal Language, to be able to compete with foreign musicians: if possible, use English. So that it can be seen by outsiders too, thus we can compete with outside musicians." This may be a consideration for Indonesian musicians to raise the country's music industry in the international arena. 


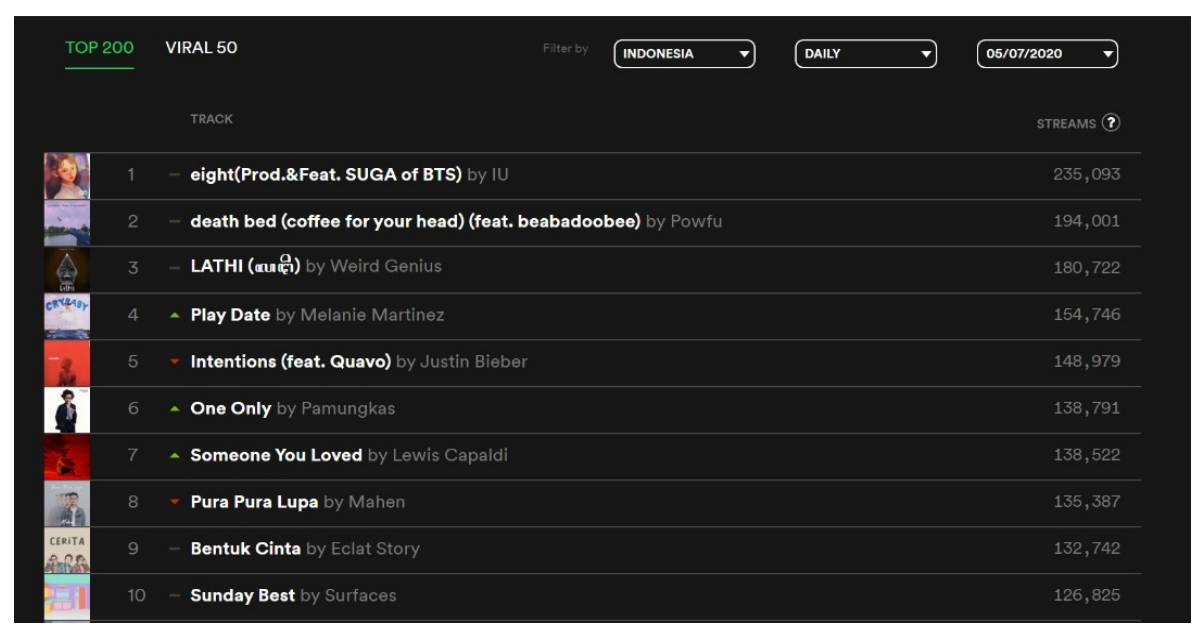

Figure 3. The dominance of Western Pop Music in Spotify (Spotify, 2020)

Political Society: Indonesian Government to Compete with Western Pop Music

One of the activities that are currently in the government's spotlight is the development of the Indonesian creative industry. The creative industry is the use of creativity, skills, and individual talents to create prosperity and employment by generating and exploiting the creative power and creativity of the individual. The creative industry is one of the current government's focuses to improve the country's economic sector, where the creative economy consists of advertising, architecture, arts, crafts, design, fashion, shows, publishing, television and radio, toys, and music. Music is one of the areas of the creative economy that is the focus of the government to improve the Indonesian music industry, which arguably must be developed with government support.

BEKRAF as the government sector engaged in advancing the creative economy has also made several efforts, such as:

(1) Bringing several Indonesian talents and the Hello Dangdut music program to SXSW; (2) Government assistance for the revitalization of creative spaces, physical facilities, and information and communication technology; (3) Digitizing Songs in Indonesian Music Museum; (4) Supporting Ambon City of World Music; (5) Organizing Indonesian Music Conference; (6) Synchronizing Fest 2016, 2017, 2018; (7) Bandung Philharmonic 2016, 2017 \& Jakarta City Philharmonic 2016, 2017, 2018; (8) Facilitating of BPJS Health and BPJS Employment for creative music players; (9) Rockshop program; (10) Music profession certification program; (11) Liztomania 2016, 2017, 2018; (12) Travel Grant to several local musicians for overseas tours; (13) Government assistance for the city of Ambon in the form of a recording studio and performance space; (14) Supporting the participation of music industry players in the Marché International du Disque et de l'Edition Musicale (MIDEM) event; and others.

However, this is not optimal, because until now Western Pop Music which is perched on the Indonesian charts is still rampant. One of the government projects with 88Rising is considered to be only a good start with unclear continuation. This is because BEKRAF has now joined a new ministry, and it is hoped that other ministries will be able to back up similar programs such as the tourism ministry; which later can also be used as a promotional event for Indonesian tourism through songs and music videos produced by the nation's children. In detail, MA as a musician said as follows:

"I really like the BEKRAF program, which was the same as 88rising at that time, it's a shame that BEKRAF was disbanded, now it's up to the new ministry for continuing it. I hope that there is something like that from the government because the unfortunate thing is that most of today's music is sponsored by the cigarette industry, everything is cigarettes, is there anything other than cigarettes, I know cigarettes are big, but try to shade them the same as the tourism ministry, for example, open selection people are taken on a tour of Asia, for example, a folk group".

Nevertheless, the government is also preparing something that is expected to be able to advance the Indonesian music industry in the international arena. This was expressed by AJG as Expert Staff to the Minister for Bureaucratic 
and Regulatory Reform at the Ministry of Tourism and Creative Economy as follows:

"So now, if we join the Ministry of Tourism and Creative Economy, of course in the future, of course, efforts will continue to be made on how we build an ecosystem. By doing so, creative economy actors, especially musicians, have a place to develop themselves, both from the initial point of view, for example, in terms of the creation of the music itself, and so on. The musicians can also be commercialized, then when they are commercialized, how do musicians get their rights, for example, the copyright is protected, so they get royalties from the announcement or publication of their works. We call all of that an ecosystem, because there are links in the chain, from creation, production, consumption, to future conservation, like that."

Those are the government's efforts to develop the music sector in Indonesia.

\section{Western (American) Pop Music as Soft Power}

Gramsci changed the meaning of hegemony from strategy (as proposed by Lenin) into a concept, just as Marxism's concept of the forces and relations of production, industry, class, and the state became a means of understanding society to change it (Sugiono, 2006). The hegemony of a class over the classes under it is the result of consensus building; the class in question is America against Indonesia. Consensus is domination that is carried out not by coercion but through agreement and understanding. Consensus is defined as an agreement, mutual agreement. Therefore, a consensus is related to psychological issues. In other words, a consensus is the obedience or submission of a person or group of people because of awareness.

In this study, it was found that a consensus was formed because the American pop music industry was very aggressive in distributing its music in Indonesia freely, without any intervention from all aspects in Indonesia. Civil society is too engrossed in the hegemony of western pop music in Indonesia, and even tends to perpetuate the hegemony itself, on the other hand, the role of political society (government) has tried to compete with western pop music by supporting various ways, but it still seems to be less massive. It cannot be a big enough resistance to the hegemony of western pop music in Indonesia.

\section{Conclusion}

The development of American pop music in Indonesia is not only an entertainment industry; but behind the spread of American Pop music, there is an effort to create a hegemony against third world countries, Indonesia in particular. American pop music is one form of media that is quite effective and efficient as a hegemonic effort, through this media one's thoughts are very easy to influence. Streaming media has also now become very important to act as a symbol of gaining and maintaining power. In this era, most people prefer American popular music to local music as is apparent from the data that researchers present. They tend to choose American pop music because of the perception that the music is more modern, offers more varied musical themes, and is more pleasurable to listen to.

It can be concluded that the hegemony of Western Pop Music in Indonesia is currently happening. The phenomenon of the dominance of Western Pop Music that occurs in the Indonesian music industry, the success of western pop music in attracting domestic audiences is shown by the increasing number of listeners of Western Pop music in Indonesia through sales figures and streaming numbers. In this case, the role of the media is still very important in determining the success of Indonesian musicians against the hegemony of western pop music, namely the radio. Currently, the official regulations controlling the rotation or broadcasting of Western and Indonesian songs are still determined by the radio, which the government has not yet touched upon. Thus, the success of a work can be said to be determined by the radio itself under their own interests.

Government support is needed to fight the hegemony of western pop music in Indonesia. The researcher considers that there have been efforts by the government to improve the country's music industry, but still, it is felt that there are many things that need to be maximized so that the growth of the music ecosystem in Indonesia becomes better to fight against the colonization of western pop music.

\section{References}

Amroshy, A. U. A. \& Imron, A. (2014). Hegemoni Budaya Pop Korea Pada Komunitas Korea Lovers Surabaya (KLOSS). 2(3), 1-8. Retrieved from https://ejournal.unesa.ac.id/index.php/para digma/article/view/9091 
Adorno, T. (1953). A Social Music of Radio Music. New York: The Free Press of Glencoe.

Apple Music. (2019). Tangga Lagu Musik Indonesia. Retrieved from https://www.applemusic.com

Ardia, V. (2014). Drama Korea Dan Budaya Popular. Lontar Jurnal Ilmu Komunikasi, 2(3), 11-18. https://doi.org/10.30656/lontar.v2i3.337

Buttigieg, J. A. (1996). Prison Notebook. New York: Columbia University Press.

Digital Sales Data. (2020). Indonesia - Overall Top Sellers Last 24 Hours. Retrieved from https://www.digitalsalesdata.com

Dominick, J. R. (2009). The Dynamics of Mass of Communication. 10th ed. New York: McGraw-Hill

Fase Berita. (2019). Sejarah Musik Pop di Indonesia. Retrieved from https://faseberita.id/entertainment/sejarah -musik- pop-di-indonesia

Gramsci, A. (1976). Selections From The Prison Notebooks, Quintin Hoare and Nowel Smith (ed). New York: International Publisher.

Hatmoko, M. D., Sumartini dan Mulyono (2014). Hegemoni Moral Nyai Kartareja Terhadap Srintil Dalam Novel Jantera Bianglala Karya Ahmad Tohari: Kajian Hegemoni Gramsci. Jurnal Sastra Indonesia, 3(1), 1-9. ISSN 2252-6315

Hills, M. (2002). Fan Cultures. London: Routledge.

Hutagalung, D. (2004). Hegemoni, Kekuasaan dan Ideologi. : Jurnal Pemikiran Sosial,
Politik dan Hak Asasi Manusia, No. 12. Retrieved from https://www.academia.edu/41602382/

Ikhsano, A. (2020) Melawan Hegemoni Perfilman Hollywood. Tangerang: Indigo Media.

Ikhsano, A. \& Stellarosa, Y. (2020). Restrictions on Some Western Songs: a Counter Hegemony Effort by the West Java Regional Indonesian Broadcasting Commission. Jurnal Komunikasi Ikatan Sarjana Komunikasi Indonesia, 5(2), 135-143.

Doi: https://doi.org/10.25008/jkiski.v5i2 .380

Indana, W. (2017). Menggenggam Dunia Lewat Musik. Retrieved from https://www.medcom.id/hiburan/indis/xk Ev5PMK- menggenggam-dunia-lewatmusik

Nezar, P., \& Arief, A. (1999). Antonio Gramsci Negara \& Hegemoni. Yogyakarta: Pustaka Pelajar.

Rojek, C. (2011). Pop Music, Pop Culture. Cambridge: Polity Press.

Suryawan, I. N. (2010). Genealogi Kekerasan Dan Pergolakan Subaltern: Bara Di Bali Utara. Jakarta: Prenada Media Group.

Storey, J. (2006). Cultural Theory and Popular Culture: An Introduction. Georgia: University of Georgia Press.

Sugiono, M. (2006). Kritik Antonio Gramsci Terhadap Pembangunan Dunia Ketiga. Yogyakarta: Pustaka Pelajar. 